Tyndale Bulletin 71.1 (2020) 115-135

\title{
A QUOTATION IN PSALM 109 AS DEFENCE EXHIBIT A
}

\author{
Steffen G. Jenkins \\ (sjenkins@ust.ac.uk)
}

\begin{abstract}
Summary
Psalm 109 contains an infamous imprecation, which roughly half of modern commentators identify as a quotation of an enemy curse. On the other hand, most who detect a quotation believe it to be aimed against the enemy anyway, in an act of poetic justice. This article assesses the debate and offers fresh grounds for a more recent proposal. The quotation includes not only curse, but an accusation, justifying the curse against David. David quotes his accuser's case, to protest that it is the fabrication of enemies who have suborned perjury. Finally, he prays that this plot against him would fail.
\end{abstract}

\section{Introduction}

Open a translation or commentary of Psalm 109 and you have a fiftyfifty chance of being told that verses 6-19 are a quotation rather than part of the prayer. ${ }^{1}$ One might well be sceptical: this seems too ethically convenient, saving us from having to pray 'the most difficult and most embarrassing psalm for conventional piety'. ${ }^{2}$ The question is

1 McCann's estimate in 'Psalms' in Introduction to Hebrew Poetry: 1 and 2 Maccabees; Psalms; Job, ed. Leander E. Keck (vol. 4 of NIB; Nashville, Tennessee: Abingdon, 1996): 1125; contra Martin J. Ward, 'Psalm 109: David's Poem of Vengeance', AUSS 18 (1980): 164.

2 Walter Brueggemann and William H. Bellinger Jr, Psalms (NCBC; New York: CUP, 2014): 473; for similar hyperbole, see Erhard S. Gerstenberger, Psalms, Part II, and Lamentations (FOTL 15; Grand Rapids, Michigan: Eerdmans, 2001): 258; David P. Wright, 'Ritual Analogy in Psalm 109', JBL 113 (1994): 385-404, esp. 392; Michael D. Goulder, The Psalms of the Return (Book V, Psalms 107-150): Studies in the Psalter, IV (JSOTSup 258; Sheffield: Sheffield Academic, 1998): 132; Norbert 
not quite that simple: if there is a quotation, what is it doing there? Whatever relief these quotation marks might bring to the reader, sanitising the psalm has not historically been the motivation for them. Hans Schmidt, usually credited for identifying a quotation, ${ }^{3}$ warned that it is futile to exonerate the psalmist via a quotation, since verse 20 asks for the quoted curse to rebound on to the enemy. ${ }^{4}$ We should not assume that identifying a quotation will bring any ethical relief, much less poison the well by impugning expositors with such a motivation. ${ }^{5}$ Despite the apparent convenience of inserting quotation marks, I hope to show that there is a good case for understanding a section of Psalm 109 as the words of David's enemy, which David offers as Exhibit A for his own defence.

Many commentators argue that, whether verses 6-19 are a quotation or not, it is what David is praying for the enemy. ${ }^{6}$ Their view hinges on a particular interpretation of verse 20 , which is more crabbed and opaque than any published translation will allow. Not only the presence but also the function of a quotation needs investigation.

Accordingly, I will begin by outlining the major arguments for and against a quotation, before offering a fresh proposal in favour of a quotation and for its intent. Verse 20 does not cast verses 6-19 against the enemy in prayer. Rather, in verse 20, David claims that the preceding verses have been a false accusation against him in court. Those bitter curses should not land on David, he says, because the evidence presented against him is false. David's real petition towards the enemies follows, and concludes the psalm.

Lohfink, 'Drei Arten, von Armut zu sprechen: illustriert an Psalm 109', TP 72 (1997): 321.

3 Hans Schmidt, Das Gebet der Angeklagten im Alten Testament (BZAW 49; Giessen: Töpelmann, 1928): 41. The idea predates Schmidt, who cited four sources.

4 Schmidt, Das Gebet der Angeklagten, 41 n.2.

5 E.g. John Eaton's complaint against Schmidt and those who follow him that 'there is no justification whatever for avoiding the natural direct meaning, however it may jar one's pious senses'; Kingship and the Psalms (SBT/2 32; London: SCM, 1976): 81 misses the mark; similarly Mitchell Dahood, Psalms III: 101-150: A New Translation, with Introduction and Commentary (AB 17A; Garden City, New York: Doubleday, 1970): 17; James Luther Mays, Psalms (Int.; Louisville, Kentucky: Westminster John Knox, 1994): 349. See also the discussion of such accusations in Allen, Psalms 101150, 102 and Zenger's refutation, A God of Vengeance? Understanding the Psalms of Divine Wrath, trans. Linda M. Maloney (Louisville, Kentucky: Westminster John Knox Press, 1996): 59.

6 E.g. Gordon Wenham, Psalms as Torah: Reading Biblical Song Ethically (Studies in Theological Interpretation; Grand Rapids, Michigan: Baker Academic, 2012): 171. 


\section{An Evaluation of Basic Arguments For and Against a Quotation}

\subsection{The Agreed Setting}

There is broad agreement about the situation described in Psalm 109. The psalmist is on trial for his life, maliciously accused by enemies. ${ }^{7}$ The danger of death is explicit (and outside any potential quotation). Courtroom language permeates the psalm. ${ }^{8}$ The courtroom could be a metaphorical setting for prayer. ${ }^{9}$ Conversely, the 'prayers' of verses $4 \mathrm{~b}, 7 \mathrm{~b}$ could be petitions in court, further underlining the juridical setting. ${ }^{10}$

\subsection{Comparison with Other Quotations}

Quotations of enemies to demonstrate their wickedness and cruelty are commonplace ${ }^{11}$ and are usually not introduced. ${ }^{12}$

7 Dahood, Psalms III, 99; Kraus, Psalmen 60-150, 291; Artur Weiser, Die Psalmen, Zweiter Teil: Psalm 61-150 (ATD 15; Göttingen: Vandenhoeck \& Ruprecht, 1987): 474; Klaus Seybold, Die Psalmen (HAT I/15; Tübingen: Mohr Siebeck, 1996): 434; Konrad Schaefer, Psalms (Berit Olam: Studies in Hebrew Narrative \& Poetry; Collegeville, Minnesota: Liturgical, 2001): 271; Allen, Psalms 101-150, 101102; David G. Firth, Surrendering Retribution in the Psalms: Responses to Violence in Individual Complaints (Paternoster Biblical Monographs; Milton Keynes: Paternoster, 2005): 36; John N. Day, Crying for Justice: What the Psalms Teach Us About Mercy and Vengeance in an Age of Terrorism (Leicester: IVP, 2005): 78; Willem A. VanGemeren, Psalms (rev. ed.; The Expositor's Bible Commentary 5; Grand Rapids, Michigan: Zondervan, 2008): 806; Frank-Lothar Hossfeld and Erich Zenger, Psalmen 101-150 (HThKAT; Freiburg: Herder, 2008): 183; Luis Alonso Schökel and Cecilia Carniti, Salmos II (Salmos 73-150) Traducción, introducciones y comentario (4th ed.; Nueva Biblia Española; Madrid: Cristiandad, 2009): 1357.

8 See the careful analysis of the legal terminology by Stephen Egwim, 'Determining the Place of vv. 6-19 in Ps 109: A Case Presentation Analysis', ETL 80 (2004): 112-30, esp. 116-18, and the general study of courtroom terminology in Pietro Bovati, Ristabilire la Giustizia: Procedure, Vocabolario, Orientamenti (AnBib 110; Rome: Pontificio Istituto Biblico, 1986): 153-96. The same conclusion is reached by, e.g. Schaefer, Psalms, 271; Allen, Psalms 101-150, 101-102; Firth, Surrendering, 36; Hossfeld and Zenger, Psalmen 101-150, 183. שֶק is false witness (see also Allen, Psalms 101-150, 102; Hossfeld and Zenger, Psalmen 101-150, 183); שפט 'outline[s] the legal process from arraignment to condemnation $(7,31)$ ' (Schaefer, Psalms, 271); שָׁ is an accuser; 'standing at the right hand' is the posture and location for both accuser and defender in court (Roland de Vaux, Ancient Israel: Its Life and Institutions, trans. John McHugh [2nd ed; London: Darton, Longman \& Todd, 1965], 156). Kirkpatrick further notes $127: 5$ as a judicial parallel for the speech in v. 2 (Books IV and V, 655).

9 McCann, 'Psalms', 1124; Seybold, Psalmen, 434.

10 Hossfeld and Zenger, Psalmen 101-150, 183; we will analyse the possibility in more detail.

11 Hossfeld and Zenger, Psalmen 101-150, 183. 
Granted, other examples of citation are rather shorter. Wenham finds it inherently unlikely that David would quote curses directed against him so comprehensively. ${ }^{13}$ However, the psalm is unusual in other ways too, and its length can be explained by the situation that gives rise to the prayer. ${ }^{14}$ I argue below that David quotes his enemy's curses in court as evidence for his defence. Therefore, 'exhibit A' needs to be presented in full. Even if it is not a quotation, then it is just as unusually long an imprecation. Its length must be explained either way.

Some object that a quotation of such length would surely require explicit introduction, ${ }^{15}$ and that there are no cues in this psalm to hint at a quotation. ${ }^{16}$ There are, in fact, several cues in the psalm pointing to an enemy quotation, to which we now turn.

\subsection{Signals of a Quotation}

\section{a. Plural Enemies}

First, in verses $1 b-5,20-31$ the enemies are always plural; in verses 619 always singular. ${ }^{17}$

Day counters that changes between singular and plural are not unknown in Psalms and can serve a specific literary purpose. ${ }^{18}$ However, he has not identified the literary function here: an explanation is surely needed for such a consistent change of number. David Wright offers a longer list of psalms examples, and good explanations for each. ${ }^{19}$

One possibility is the editing of two older prayers, resulting in accidentally highlighting an individual. ${ }^{20}$ This does not explain why

\footnotetext{
12 Schmidt, Das Gebet der Angeklagten, 41; Allen, Psalms 101-150, 103; Hossfeld and Zenger, Psalmen 101-150, 183.

13 Wenham, Psalms as Torah, 173.

14 Thijs Booij, 'Psalm 109:6-19 as a Quotation: A Review of the Evidence' in Give Ear to My Words, ed. Janet Dyk (Amsterdam: Societas Hebraica Amstelodamensis, 1996): 91-106, esp. 105.

15 David Wright, 'Ritual Analogy in Psalm 109', JBL 113 (1994): 385-404, esp. 394 n.23.

16 Day, Crying, 157 n.14.

17 Kraus, Psalmen 60-150, 920; Weiser, Die Psalmen, Zweiter Teil, 474-75; Hossfeld and Zenger, Psalmen 101-150, 183.

18 Day, Crying, 157 n.14.

19 Wright, 'Ritual Analogy in Psalm 109', 394 n.22.

20 Wright, 'Ritual Analogy in Psalm 109', 397, 399-400.
} 
such an editor would be content to allow the accidental focus on one individual to remain. I will explain that deliberate focus below.

Some object that verses 13-15 are plurals. ${ }^{21}$ However, these are references to the plurality of his relatives, ${ }^{22}$ or sins of his plural ancestors. $^{23}$

This consistent, well-demarcated switch between plural enemies and a singular target is by no means the only indicator of a quotation.

\section{b. The Switch from Quotation to Petition in Verse 21}

The verbless construction and unusual syntax of verse 20 suggests a

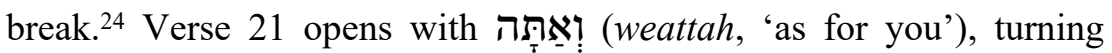
from a report of the peril to addressing Yahweh. ${ }^{25}$ If all the preceding has been David's imprecation, it is not clear what contrast the syntax is marking. Verse 28 makes explicit that the enemy is cursing, and Yahweh is asked to bless instead, while it is in verse 29 that we find a petition concerning the enemy, from which Kraus argues that the preceding was not a petition. ${ }^{26}$ Verse 28 would work particularly well

21 Jean-Luc Vesco, Le psautier de David: traduit et commenté (Lectio Divina 211; Paris: Cerf, 2006): 1045; Goulder, The Psalms of the Return, 137.

22 Throughout vv. 6-19 the prayer is that the family of the individual should suffer, and that is reflected in the plurals here: 'their name' is the name of his posterity. שִמשם

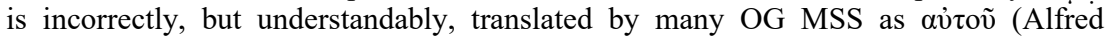
Rahlfs, ed., Psalmi Cum Odis [vol. 10 of Septuaginta Societatis Scientiarum Gottingensis; Göttingen: Vandenhoeck \& Ruprecht, 1931]: 275). Most ETT follow MT, though ESV, GNB, NRSV, RSV, and Horsley have singular. Some offer 'his family name' (NLT). Others pluralise 'name', 'their names' (NIV).

23 In v. 15 it is the sins of his ancestors from v. 14 which are in view; their (plural) sin should always be remembered. Here again, some LXX MSS offer aṽ

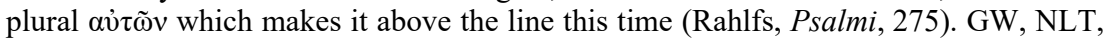
NRSV, RSV alone have a singular. The same would apply to v. 10b if Alfred Guillaume's emendation were correct, 'And on the morrow may their [i.e. his children's, 10a] dwellings be obliterated' ('Note on Psalm 109:10', JTS 14 [1963]: 9293, esp. 93).

24 Day, Crying, 156 n.14.

25 Hans-Joachim Kraus, Psalmen 60-150 (vol. 2 of Psalmen; 5th ed.; BKAT 15; Neukirchen-Vluyn: Neukirchener, 1978): 921.

26 Psalmen 60-150,921. A form-critical perspective would note that Gunkel had argued that וְֵָת opens the Bitte sections of laments (Hermann Gunkel and Joachim Begrich, Einleitung in die Psalmen: die Gattungen der religiösen Lyrik Israels [Göttinger Handkommentar zum Alten Testament; Göttingen: Vandenhoeck \& Ruprecht, 1933]: 480), so that what precedes it must belong to the Klage (Pirmin Hugger, “"Das sei meiner Ankläger Lohn ..."? Zur Deutung von Ps 109,20', BibLeb 14 [1973]: 105-12, esp. 109). However, this ignores the frequent repetition and interweaving of Bitten and Klagen, as indeed in vv. 21-29 (David P. Wright, 'Ritual Analogy in Psalm 109', 394-95). For the same reason, the presence of a petition at v. 
in the drama of the psalm if the curse mentioned in that verse has been quoted. ${ }^{27}$

Moreover, in verse 6 (within the quotation) the enemies place an enemy at his right-hand side, to condemn him (v. 7), whereas the psalmist ends with the confidence that Yahweh is at his right-hand side instead (v. 31a). ${ }^{28}$ I would argue that it is important to distinguish the singular accuser whose words are quoted in verses 6-19 from the wider group referred to in verses 21-31.29

Jean-Luc Vesco notes that (יה-y-h, 'to be') appears nine times to intensify the imprecations and that this spans the divisions above, making the supposed quotation implausible. ${ }^{30}$ However, the first eight are volitives ('may it/he be') and are all inside our proposed quotation (vv. 7,8,9,12 bis, 13,15,19). Verse 25 is outside the quotation and is indicative ('I am'), contrasting the desire of the accusers in the previous eight instances with David feeling the effects of their work against him. Vesco's observation favours a quotation.

Verse 20 is not explicitly a petition, despite translations. It is verbless and has further ambiguities, to be explored below. I will argue that it is an exclamation, where David blames unseen conspirators for the curse he has just quoted.

\subsection{Interim Conclusion}

As the literature cited demonstrates, these points are arguable, but there is a case to answer. The nature of other quotations raises the possibility that there could be one here. There are significant signals in the text to indicate a quotation. The content of the alleged quotation might also be incompatible with the petitions outside the quotation, as discussed below. Before reaching a conclusion, we look in more detail at verses that lead to and follow verses 6-19, the seams either side of that block, and its internal divisions.

28 does not mean that vv. 6-19 cannot be petitions (contra Kraus, Psalmen 60150, 921).

27 Allen, Psalms 101-150, 103; Hossfeld and Zenger, Psalmen 101-150, 184.

28 Kraus, Psalmen 60-150, 921.

29 Firth's explanation of the singular as highlighting a ringleader of the group (Surrendering, 38) is right, in my view, but the ringleader is the accuser whose words might be quoted in vv. 6-19. McCann's suggestion that the last of a string of accusers is singled out seems arbitrary ('Psalms', 1125).

30 Vesco, Le psautier, 1044. 


\section{Verses 6-19, the Build-up and the Follow-up}

\subsection{One Mouth or Many? Verse 2}

Neglected in most discussions is the significance of the singular speaker announced in verse 2, who is engaged in verse 6 by the enemies of verses 2-5. Verse 2 causes several difficulties and proposed emendations: ${ }^{31}$

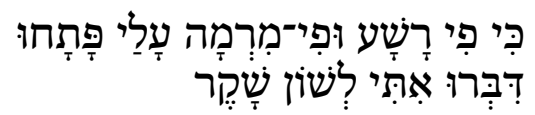

Firstly, does פתח (p-t-kh, 'to open') here mean that the person speaking opens his own mouth, or that someone else causes him to speak? Secondly, should the person be understood as plural rather than singular, or should one of various emendations be adopted to give a consistent plural?

\section{a. Transitive or Reflexive?}

The verb פתח (p-t-kh) occurs frequently in the qal in relation to opening a (peh, 'mouth'), and twice in the nip 'al. ${ }^{32}$ The qal can be both transitive (opening someone else's mouth: Josh. 8:17; 22:28; Ezek. 3:2,27; 33:22; Ps. 51:17) or reflexive (Num. 16:32; 26:10; Isa. 53:7; Ps. 38:14; 39:10; 78:2; Job 3:1; 33:2; Prov. 24:7; 31:8,9,26; Dan. 10:16). Some suggest emending to nip 'al, ${ }^{33}$ where opening a 'mouth') only occurs twice, once reflexive and once transitive. ${ }^{34} \mathrm{We}$ cannot conclude transitivity or reflexivity from either binyan in connection with mouths opening. The following four verses provide the answer.

31 English translations make various changes here, discussed below, which is why I delay offering my own rendering until a couple of paragraphs' time.

32 Contra John Goldingay, Psalms 90-150 (vol. 3 of Psalms; Baker Commentary on the Old Testament Wisdom and Psalms; Grand Rapids, Michigan: Baker Academic, 2008): 273 n.1.

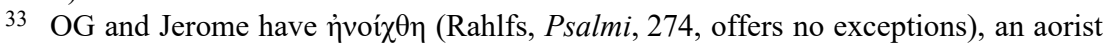
passive which could suggest a nip 'al, as also Syr. This leads some to the emendation נִפּתחתוּ (rejected by Kraus, Psalmen 60-150, 919). Others, noting that the versions are singular, opt for the qal passive participle פָּתוּ (Seybold, Psalmen, 433). Goldingay suggests that the aorist passive is the result of the translator's decision, not a reflection of a different Vorlage (Psalms 90-150, 273 n.1). Targums have a pe'al plural. It seems that the emendation is to be rejected.

34 In Ezek. 33:22 we see a contrast: the qal indicates God opening the mouth of the mute man, who then goes on to open his own mouth (nip 'al) by speaking. However, in the prediction of this event (Ezek. 24:7) the nip 'al seems transitive. 


\section{b. Singular or Plural?}

The mouth in verse 2 is singular, despite common translations. While Hebrew can use a singular for a plural, we should not assume that the singular here is insignificant. If we understand the verb as transitive, we have a plurality of agents all causing a single man to speak. This is also what we see immediately following, as verses 3-5 describe a plural enemy attacking with words of accusation, while in verse 6 they appoint a single spokesman to accuse David. Indeed, the same man as verse 2: compare עָלָליו רָשָָע ('alay rasha', 'evil against me', v. 6) with רדּשָׁ (rasha' ... 'alay, 'evil ... against me', v. 2). In the second colon we have a plurality speaking (דִ דִ dibberu, 'they say') with a singular tongue (לְְשון שֶׁקֶר leshon sheqer, 'slanderous tongue'). ${ }^{35}$

The plural in the second colon matches the agents of the first colon, who have opened the deceitful mouth of one wicked man. Hence this rendering of verse 2 :

For a wicked man's mouth, yea a mouth of deceit, have they opened against me:

They have spoken with me with a tongue of falsehood. ${ }^{36}$

35 If the verb of v. 2a were understood reflexively, the plural would imply that the mouth of the wicked man is different from the deceitful mouth. This leads to the

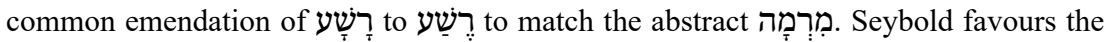
emendation to רֵֶׁׁ because he thinks it makes sense of the plurals of $v$. 3 (Psalmen, 433). Wright points out that is abstract (mouth of wickedness), thus parallel to מִרְמה (mouth of deceit), and would lend itself to plural translation. He thinks that was the original reading. He argues that רִשָ "came about in order to solve the problem of the singular enemy in vv. 6-19. By understanding v. 2 as speaking about the enemies' opening the "mouth of a wicked person", a distinction between a group of enemies and a particular individual enemy was made already at the beginning of the psalm' ('Ritual Analogy in Psalm 109', 395 n.27). However, retaining the single mouth and tongue and the plural verbs is the harder reading in the immediate context, but fits nicely with the broader context, especially v. 6. Translators of versions who wrestled with the larger context would not need to emend away from how to read the immediate context fittingly; on the other hand, if they were only looking at the verse itself and perhaps the next one, it is understandable that they would seek the various emendations or translations that are evident.

36 Kirkpatrick, Books IV and V, 654; similarly, Franz Delitzsch, Die Psalmen (5th ed.; Leipzig: Dörflin u. Franke, 1894; repr., Giessen: Brunnen, 1984): 673; J. J. Stewart Perowne, The Book of Psalms: A New Translation (5th rev. ed; London: Bell, 188283): 288-89; Goulder, The Psalms of the Return, 132, 135-37; Beat Weber, Die Psalmen 73 bis 150 (vol. 2 of Werkbuch Psalmen; Stuttgart: Kohlhammer, 2003): 215; Vesco, Le psautier, 1041; Hossfeld and Zenger, Psalmen 101-150, 176; Goldingay, Psalms 90-150, 273; ASV; NASB. By contrast, many renderings offer: 'For the mouth of the wicked man and the mouth of deceit are opened against me ...' (Darby), or smooth everything in v. 2 as singular (Schökel, Salmos II, 1354) or plural (ESV, GW, GNB, HCSB, LEB, MSG, NET, NCV, NIV, NLT, NRSV, RSV). 
It makes good sense to understand the mouth of one wicked man, described further as a mouth of deceit. In that case, the first construct identifies the owner of the mouth; the second describes its quality. Those who open this singular mouth continue to speak through a single person: the single slanderous tongue of the second colon. In verses 3-6, these conspirators use words as weapons, to encircle and accuse (vv. 34), as an expression of hatred (v. 5), and have appointed one wicked man against David (v. 6a), one accuser for him (v. 6b).

\subsection{Project Perjury: Verses 4-7}

Verses 4-7 span the opening seam of the section where the target becomes singular (vv. 6-19), creating a link between David's prayer and his quotation. Their accusing (שטן $s-t-n)$ in verse 4 is matched by

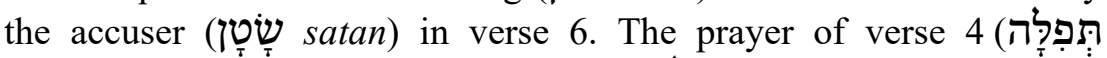

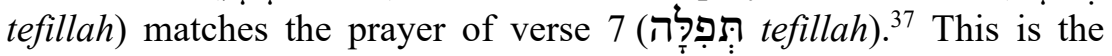
transition from general accusations to a courtroom. When they respond to his love with accusation, David gives himself to prayer in verse

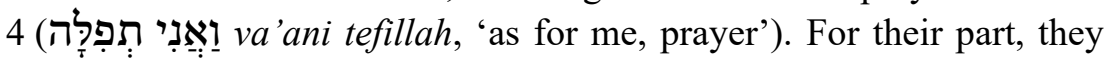
conspire to have him face a rigged trial. The accuser is wicked (v. 6) in that he will give false evidence against David. In verse 7 they want him to be found guilty, and for his 'prayer' to be reckoned as sin. This may mean that he is accused of 'praying' sinfully, namely cursing (as in vv. 16-19).

Alternatively, if this 'prayer' is his petition in the trial, it illustrates their desire that he be forsaken even by God. Describing the appeal to

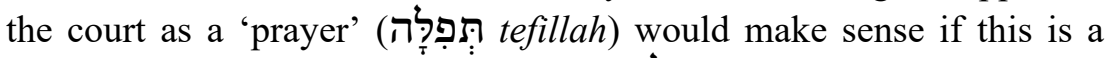

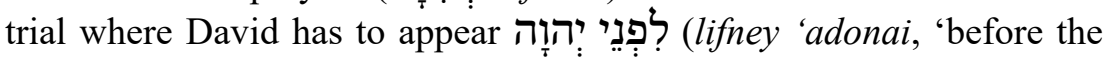
LORD', Deut. 19:17). ${ }^{38}$ His appearing before the human court of priests

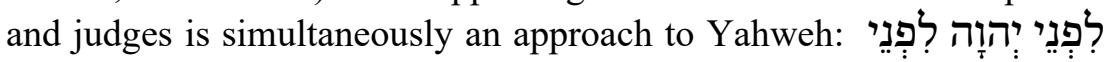

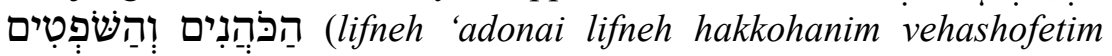
'before the LORD - before the priests and judges'). ${ }^{39}$

37 If, following Syr., the second colon is understood to mean that he is praying for them (Kraus, Psalmen 60-150,919), then the petition of v. 7 would illustrate the truth of v. $4 \mathrm{a}$.

38 We find this sense of judicial arbitration for the root פלל in Exod. 21:22; Deut. 32:31; Job 31:11,28; Isa. 28:7, from which Schökel concludes that David is appealing to the judgement of God or of the temple (Salmos II, 1361). So also Seybold, Psalmen, 435; Egwim, 'Determining the Place of vv. 6-19', 124 n.45.

39 If Zenger is correct, and this psalm is simultaneously a court case and a prayer to Yahweh to oversee the case, the lines between prayer and speech in court become blurred (Hossfeld and Zenger, Psalmen 101-150,183). If E. A. Speiser is right in his 
Since Yahweh is seen as the judge over all others (Deut. 19:17; Exod. 22:7-10, 34:7; $1 \mathrm{Kgs}$ 18:31-32), the equivalence would make sense. In his study of legal terminology, Bovati notes that 'prayer' is used in general by the accused, ${ }^{40}$ and that the verb פלל ( $p$-l-l, 'pray') is especially used when unjustly accused, to highlight the fact that their ordeal bears little resemblance to a just court-case. ${ }^{41}$ For the

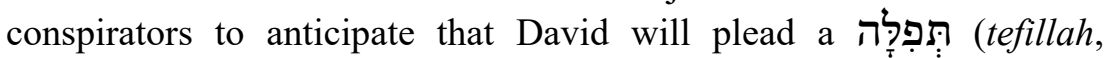
'prayer') is, therefore, a significant clue that they are rigging the trial. The adjective שֶׁקֶ (sheqer, 'false, worthless') is particularly appropriate for witnesses in court (Deut. 19) ${ }^{42}$ In any event, verses 6-7 are a plan to prosecute and not part of the prosecution itself. ${ }^{43}$

On any of these readings, verses 8-15 would be the desired sentence from the court. ${ }^{44}$ I would suggest that verses 6-7 are a report of the wicked deliberations of the slanderous enemies, but are not a direct quotation of their representation to the court. They cannot have asked the court to pervert its own processes in verse 6 , but they have deputised a single accuser to slander David in court (v. 6b). ${ }^{45}$

Even if all of verses 6-19 are a quotation, it seems implausible that David could ask for verses 6-7 against his enemies. This incongruity is often noticed as evidence for a quotation, which some seek to resolve by appeal to the lex talionis (see Exod. 21:23-24; Lev. 24:19-20). ${ }^{46}$ However, while a wicked accuser may be poetic justice, it is not lawful. ${ }^{47}$ Deuteronomy 19 requires the false witness to suffer the

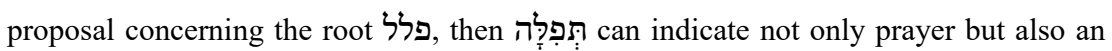
appeal to a judge for right assessment ('The Stem PLL in Hebrew', JBL 82 [1963]: 301-306, esp. 305).

40 Ristabilire la Giustizia, 109.

41 Ristabilire la Giustizia, 286 n.128.

42 So also McCann, 'Psalms', 1125.

43 So Seybold, Psalmen, 435; Wright, 'Ritual Analogy in Psalm 109', 397; McCann, 'Psalms', 1126. Others also set vv. 6-7 apart in various ways: Egwim, 'Determining the Place of vv. 6-19', 119; Hossfeld and Zenger, Psalmen 101-150, 183. The clash in tone between v. 6 and the rest of the section causes Gerstenberger to believe the verse has been tampered with (Psalms, Part II, 260).

44 Seybold, Psalmen, 435.

45 Egwim notes that v. 7 demonstrates a rigged and unjust court case ('Determining the Place of vv. 6-19', 120). However, he understands the evil man of v. 6 as a wicked judge rather than an accuser ('Determining the Place of vv. 6-19', 125). This seems unlikely in view of his description as a שָָָׁ (cf. Schaefer, Psalms, 271). Seybold incorrectly thinks that the right hand is reserved for the defence, and so detects a second person in v. 6b, an accuser where a defender should be (Psalmen, 435).

46 E.g. Wright, 'Ritual Analogy in Psalm 109', 395 n.25; Day, Crying, 78-79.

47 McCann 'Psalms', 1126; contra Vesco, Le psautier, 1046. 
sentence that he had asked for, but not a re-enactment of a trial with a wicked witness. The lex talionis does not allow poetic miscarriages of justice. ${ }^{48}$

Verses 8-15 follow naturally from verse 7 as the result of the failed prayer/plea. There are two acts of speech against David: the conspiracy of the group, and the words of the accuser in court. Here we have the single mouth and tongue of verse 2a being hired in verse 6: רִָָָֹ (rasha', 'evil') again. ${ }^{49}$

In court, where enemies feign to seek justice, verses 8-15 are presented as fitting punishment for David. In what follows, in verses 16-19, to which we turn next, he stands accused of having caused something similar to someone else.

\subsection{The Charge against David (vv. 16-19)}

The verbs in verses 17-18 are frequently emended. After the qatal זָכָ (zakar, 'he remembered') in verse 16, every finite verb in verses 16-17 is wayyiqtol: vayye'ehav ... vatevo'ehu, 'he pursued ... he loved ... it came upon him'). Verse 17 turns to a negated qatal form, in semantic parallelism

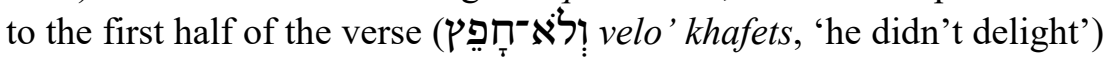

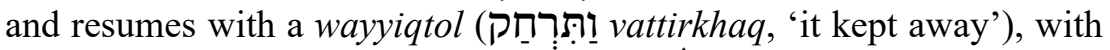

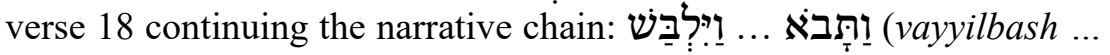
vattavo', 'he clothed himself ... it came/went'). There is nothing volitive (no petitions) in these verses. It is in verse 19 that the whole thing is summed up with an unambiguous jussive: (tehi, 'let it be'). ${ }^{50}$

The desire to emend the second verb in each colon of verses 17-18 to a jussive is understandable; that would give three pairs, each moving from past accusation to a prayer for poetic justice. ${ }^{51}$ The Old Greek translation (OG) is usually enlisted in support. ${ }^{52}$ However, in each of

48 Contra Wright, who cites $5: 11 ; 7: 16-17 ; 9: 16 ; 28: 4-5 ; 35: 8 ; 54: 7 ; 57: 7 ; 94: 22-23$; 141:10 ('Ritual Analogy in Psalm 109', 395 n.25). None of the verses cited involve asking for a perversion of justice.

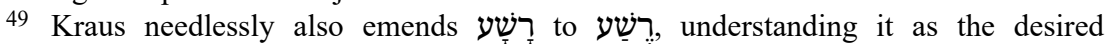
proclamation of the judge over the accused (Psalmen 60-150, 919, 922).

50 Readers less comfortable with linguistic niceties may wish to skip the next two paragraphs.

51 So Vesco, Le psautier, 1048; Seybold, Psalmen, 435.

52 Kirkpatrick, Books IV and V, 658; Kraus, Psalmen 60-150,919; Gianfranco Ravasi, Il libro dei Salmi: commento e attualizzazione. Vol. III, 101-150 (Lettura 
the three verbs, the OG offers an indicative (future or aorist). ${ }^{53}$ While the future indicative can be a weak imperative in Attic, not so in the OG. In the OG it can function as an imperative in legal texts (as an obvious Hebraism), but only in the Pentateuch. ${ }^{54}$

Positively, the OG translator of this psalm has been quite consistent throughout: these indicatives are consistent with wayyiqtols and not with jussives. ${ }^{55}$ Most significantly, the forms proposed as emendations (waw + jussive) do appear in the psalm: in verse $15 \mathrm{~b}$ it is rendered optative, in verse $27 \mathrm{a}$ imperative. OG uses the future in four other places (vv. 28a $\alpha, \beta, 30 \mathrm{a}, \mathrm{b})$ each rendering an imperfect. Wayyiqtols are rendered as aorist (vv. 16b,17a $\alpha$ ), imperative (v. 28b), and future (v. $17 \mathrm{a} \beta)$. The evidence seems clear: when the translator detected a volitive, he rendered it as a volitive; when he detected a future, he rendered a future; when faced with a wayyiqtol, he translated contextually. Had the Vorlage had a jussive (either in form or apparent meaning), he would have translated with an imperative, subjunctive, or optative. It seems that the MT and the OG Vorlage match, as seen in modern translations of the OG. ${ }^{56}$ Targums also match MT, relating a past narrative before verse $19 .{ }^{57}$

While the emendation has wide support in translations and commentaries, ${ }^{58}$ the MT is followed frequently. ${ }^{59}$ MT begins the

pastorale della Bibbia 12; Bologna: Dehoniane, 1985): 233 n.8; Allen, Psalms 101150, 99 n.17a; Vesco, Le psautier, 1048 n.3.

53 Rahlfs, Psalmi, 275, without exception in the MSS.

54 Blass-Debrunner-Funk §362; F. C. Conybeare and St. George Stock, A Grammar of Septuagint Greek (Grand Rapids, Michigan: Zondervan, 1980): §74. Psalm 109 is not legislation and none of Conybeare's examples are from outside the Pentateuch.

55 When there is a command, OG renders it as a command in Ps. 109. Prohibitions are rendered with $\mu \eta$ + subj. (v. 1); $\mu$ ' + imperative (v. 12 bis); $\mu$ í + optative (v. 14b). Imperatives are rendered with imperative (vv. 6,21a,26a,26b). Two morphologically clear jussives appear, and both are rendered in the imperative (vv. 13b,19a $\alpha$ ); two $w^{e}$ qatal forms follow from jussives and are rendered as imperatives (vv. 10a $\alpha, 10 \mathrm{~b}$ ). Yiqtols with jussive meaning are rendered in the imperative (vv. 6,7b,8a,9a,10aa, 11a, $11 \mathrm{~b}, 13 \mathrm{a}, 15 \mathrm{a})$ or optative (vv. 7,8b,14a).

56 See also Derek Kidner, Psalms 73-150: A Commentary on Books III-V of the Psalms (Leicester: IVP, 1975): 425; Wright, 'Ritual Analogy in Psalm 109', 397.

57 David M. Stec, The Targum of Psalms: Translated, with a Critical Introduction, Apparatus, and Notes (The Aramaic Bible 16; Collegeville, Minnesota: Liturgical, 2004): 201.

58 Darby; ESV; GNB; HCSB; LEB; KJV; MSG; NCV; NIV; NLT; NRSV; RSV; Seybold, Psalmen, 433; Louis Jacquet, Psaumes 101 à 150 (vol. 3 of Les Psaumes et le Cour de l'Homme; Gembloux: Duculot, 1977): 192.

59 ASV; GW; NET; NASB; YLT; Perowne, Psalms, 292; Kirkpatrick, Books IV and V, 658; Kidner, Psalms 73-150, 425; Delitzsch, Psalmen, 671; Ravasi, Salmi (101- 
grounds for prosecution with יַעַן (ya'an 'asher, 'because') followed by a standard past narrative of a qatal followed by a wayyiqtol chain, leading to a single petition with the jussive of verse 19.60

We have first a description of the general wicked behaviour of the opponent. He didn't like blessing, and it remained far from him. The enemy has what he wants, not what he dislikes. We pray that his cursing will become like a garment wrapped around him. The jussive of verse 19 is thus the conclusion of the description of past events introduced with יעַן אַשֶׁ (ya'an 'asher, 'because') and spanning verses 16-18.

The sense is not that curses came against him, but from him. ${ }^{61}$ Verse 19 is poetic justice: he is cursed. He had enjoyed wearing a coat of cursing, but this one will cling forever. ${ }^{62}$

Verses 16-19 are the charge sheet: ${ }^{63}$ they tell the history and character of the accused, and end by showing that the sentence being asked for (vv. 8-15) is fitting for him (v. 19). The opening יעַן אֶשֶׁר

150), 232; Goulder, The Psalms of the Return, 137-38; John Eaton, The Psalms (London: T\&T Clark, 2003): 381; Weber, Psalmen 73-150, 216; Goldingay, Psalms 90-150, 274; Hossfeld and Zenger, Psalmen 101-150, 177; Anne Marie Kitz, 'Effective Simile and Effective Act: Psalm 109, Numbers 5, and KUB 26', CBQ 69 (2007): 440-56, esp. 445. Amos Hakham offers both options in Psalms 101-150 (vol. 3 of The Bible: Psalms with the Jerusalem Commentary; Jerusalem: Mosad Harav Kook, 2003): 127.

60 Calvin is at least consistent in translating even the beginning of v. 18 as a jussive (Psalms, 4:283), so that he seems to be taking qatal forms as past and wayyiqtols as volitive. Vesco's claim that the jussive in v. 19 implies that the events of vv. 17-18 are not complete does not do justice to the text (Le psautier, 1042 n.3). Kidner intriguingly asks why we would add more imprecations to a psalm already so replete with them (Psalms 73-150, 425). Wright argues that garments in v. 28 refer to the future, so any reference to them here must also be future (David P. Wright, 'Ritual Analogy in Psalm 109', 397-98). However, the argument of vv. 16-19 reasons from the past to the future using this metaphor; Wright's logic should push us to emend every verb in vv. 16-19 to a future tense. Without emendation, Calvin seems to think the grammar is plastic enough that interpretation should drive translation with regard to the tenses (Psalms, 4:284; Day follows him uncritically here: Crying, 155 n.4).

61 Goldingay, Psalms 90-150, 284; Kirkpatrick, Books IV and V, 658.

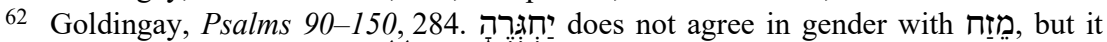
refers to the feminine curse (קָלָלָָה), consistent with the feminine jussive that opens the verse (cf. Wright, 'Ritual Analogy in Psalm 109', 398 n.34).

63 Seybold, Psalmen, 435; Vesco, Le psautier, 1047; Wright, 'Ritual Analogy in Psalm 109', 397. 
(ya'an 'asher, 'because') markedly breaks off from the preceding and introduces a rationale. ${ }^{64}$

The question remains: are verses 16-19 within the quotation, or part of David's speech?65 We must delay judgement until we have examined verse 20 .

\subsection{The Counter-Accusation (vv. 20-21)}

Verse 20 is ambiguously terse, so unavoidable translation decisions import a great deal of interpretation into the rest of the psalm:

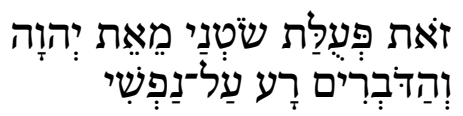

This the work/reward of those who accuse me from[?] Yahweh and who are speaking evil concerning me.

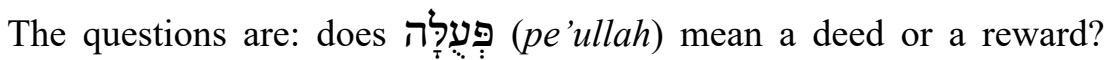
What does מֵאת יְְוָה (me'et 'adonai, 'from Yahweh'?) mean? Is it a

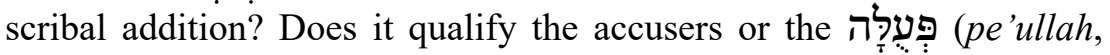
'deed/reward')? What is the grammatical mood of the verbless .... פִּעִ (zot pe'ullat, 'this ... the work/deed of...')?

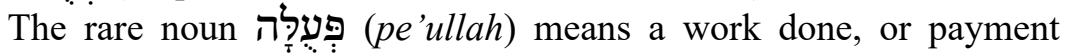
earned by that work (whether reward or, arguably, retribution). ${ }^{66}$ It could be taken either way here. ${ }^{67}$

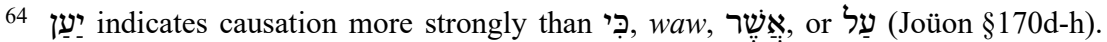
Wright also notes a stylistic shift in the metaphors used before and after v. 16 ('Ritual Analogy in Psalm 109', 397).

65 The distinct role of these verses needs consideration, since even some commentators who retain them within the quotation set them apart in some way (Kraus, Psalmen 60-150, 923; Weiser, Die Psalmen, Zweiter Teil, 474; Hossfeld and Zenger, Psalmen 101-150,183), while others exclude them from the quotation (Louis Jacquet, Psaumes 101 à 150, 188; Schökel, Salmos II, 1360; NJB). It is not clear why Schaeffer thinks 'it is unlikely that the wicked would accuse the psalmist of oppressing the defenseless and loving the curse (vv. 16-19)' (Psalms, 270). If vv. 6-15 is a fitting punishment for the crime of vv. 16-19, then it is just as possible for the wicked accusers to be seeking David's life because of his lack of charity (vv. 16-19) as it is for David to demonstrate that his accusers lack charity with vv. 16-19. The fact that the verdict will rebound on the accusers makes it difficult to decide definitively.

66 Firth argues with the majority for 'reward' as its only ironic use in the OT

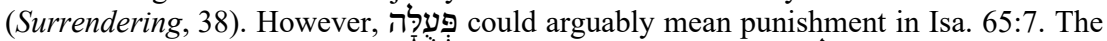
term may simply be neutral, depicting the consequence of doing פעל, for good or ill, in which case the sense need not be ironic in Ps. 109:20. However, Harold Creager points out that neither פעל nor any of its cognates ever has a negative meaning ('Note on Psalm 109', JNES 6 [1947]: 121-23, esp. 122).

67 When related to שָככסר (payment, wage) it can have either sense: in Isa. 40:10, 62:11

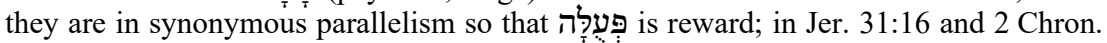


Kraus is confident that מֵֵֵת :יהוֹה (me'et 'adonai) should be removed. He thinks it an explanatory gloss which has misled exegetes

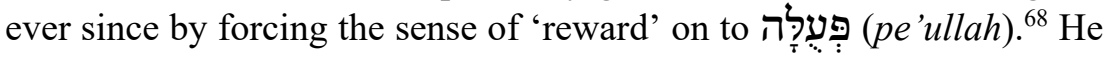
sees the verse as announcing that the foregoing has been a quotation of the enemy, their work of accusing David. However, Kraus cites no versions in support of his bold emendation. ${ }^{69}$ It is also not true that every exegete in history has been misled in this way. ${ }^{70}$

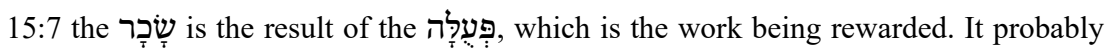
refers to reward in Lev. 19:13; Isa. 49:4; 61:8; Ezek. 29:20. It could be taken either way in Isa. 65:7 (cp. John D. Watts, Isaiah 34-66 [WBC 25; Dallas: Word, 1998]: 339; with K\&D, 7:616-17). Also Prov. 10:16; even in the context of the preceding verse, the parallelism with the gain of the wicked in the second half of the verse could be contrastive; it is taken as 'labour' by ASV; Darby; KJV; HCSB; NKJV; while the majority view is 'reward' as ESV; GNB; GW; LEB; MSG; NASB; NCV; NET; NIV; NIrV; NLT; NRSV; RSV; YLT; K\&D, 6:159; Duane A. Garrett, Proverbs, Ecclesiastes, Song of Songs (NAC 14; Nashville, Tennessee: Broadman \& Holman, 1993): 119; Rowland E. Murphy, Proverbs (WBC 22; Dallas: Word, 1998): 70. Finally in 11:18 ('work': Darby; KJV; NKJV; 'wages': ASV; ESV; GNB; GW; HCSB; LEB; MSG; NASB; NCV; NET; NIV; NRSV; RSV; YLT; Murphy, Proverbs, 79; Garrett, Proverbs, Ecclesiastes, Song of Songs, 124. The ambiguity is captured by K\&D, 6:174). It occurs in two other Psalms, probably meaning 'work': 17:4; 28:5.

68 Kraus, Psalmen 60-150, 920-21; so also Creager, 'Note on Psalm 109', 122-23.

69 Alep is hard to read here, but the words are clearly present rather than missing (Moshe Goshen-Gottstein, ed., The Aleppo Codex: Part One: Plates [Jerusalem: Magnes, 1976]:תקכד, cf. Cohen, Psalms [II], 136). L is crystal clear and the words are there (David Noel Freedman, general editor, The Leningrad Codex: A Facsimile

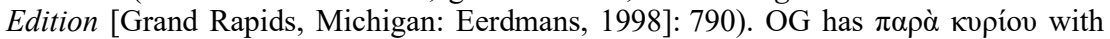
some MSS showing кupí $\omega$, but none omitting the phrase (Rahlfs, Psalmi, 275). Augustine supports the genitive (Enarrat. Ps. 109:19 [NPNF 1 8:539]). Targums have

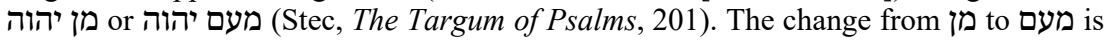
consistent with a general trend in Targums to put distance between God and man in their dealings. See for instance Jon. 1:1-2, where MT has a simple construct for the

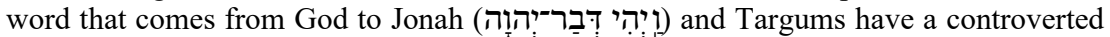

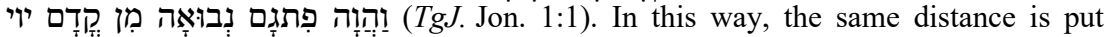
between God and his word as is evident in v. 2 when the trouble comes before him,

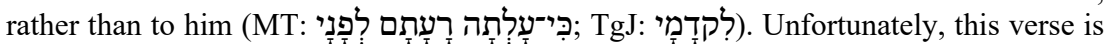
just missing from 11QPs ${ }^{\mathrm{a}}$, frag. D (Eugene Ulrich, ed., The Biblical Qumran Scrolls: Transcriptions and Textual Variants [VTSup 134; Leiden: Brill, 2010]: 695; James A. Sanders, The Psalms Scroll of Qumrân Cave 11 [11QPsa] [DJD 4; Oxford: Clarendon, 1965], plate III). Syriac, while difficult, certainly includes יהוה and probably derives from a single word division, reading שטטנים את־יהוה, so that Yahweh becomes the direct object and the accusers are plural and have no object suffix. There is no call here to remove the phrase or even alter it (A. Vogel, 'Studien zum Pešița-Psalter', Bib 32 [1951]: 32-56, 198-231, 336-63, 481-502, esp. 209). For a brief description of the proposals concerning Syriac, none of which remove the phrase entirely, see Allen, Psalms 101-150, 99 n.20a.

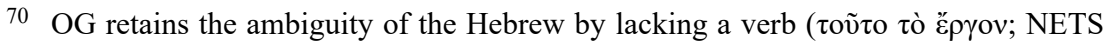
has 'This is the work' with 'May this be the work' relegated to a footnote). Augustine emphatically denies that the preceding is their reward (Enarrat. Ps. 109:19 [NPNF ${ }^{1}$ 8:539]). Targums retain the ambiguous lack of verb, but in some MSS replace אחשנא 
Nonetheless, while the ancient versions usually understood (pe'ullah) as 'work', ${ }^{71}$ most interpreters take it as 'punishment': David requesting that the preceding (זָ zot, 'this') should be the 'reward' of those who have falsely accused him, to be meted out by Yahweh. ${ }^{72}$ Quotation marks do not necessarily bring ethical relief, nor have they done so historically.

Retaining מֵאֵת יִהוָה (me'et 'adonai), we still need to ask what it

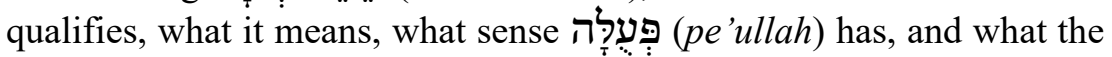
mood of the implied verb is.

I would suggest that the judicial context implies a spatial sense for

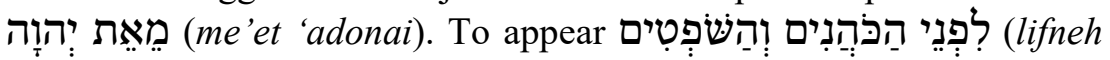
hakkohanim vehashofetim, 'before the priests and judges') and make an accusation is to appear לִפְני יִיהוָה ' (lifneh 'adonai, 'before the LORD') (Deut. 19:17). One goes physically into the presence of the priests and judges, but through their mediation one is in Yahweh's presence. The shock is not that a group is accusing David with reference to Yahweh or his law. ${ }^{73}$ The surprise is the location from which they make the accusation: they are standing in the presence of Yahweh, accusing David from Yahweh's side. ${ }^{74}$

The point is to contrast the position of the accuser and defender: in verse 6 the accuser was simply to be put at the victim's right hand

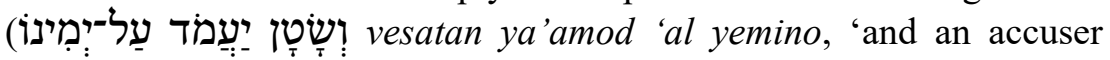
stands at my right'), but he has to stand at Yahweh's side to accuse. Therefore, the psalm concludes with Yahweh himself standing at David's right-hand side (כִי־יעְמָד לִימִין אֶבְיוֹ ki ya'amod limin 'evyon,

\footnotetext{
'heritage' with עובד 'work' (Stec, The Targum of Psalms, 201). As we will see below, Zenger retains the verse intact, without being misled into viewing a petition for a reward either (Hossfeld and Zenger, Psalmen 101-150, 177, 189).

71 Creager, 'Note on Psalm 109', 122.

72 This holds whether it is seen as a quotation (e.g. Schmidt, Das Gebet der Angeklagten, 41; Stephen Egwim, A Contextual and Cross-Cultural Study of Psalm 109 [Leuven: Peeters, 2001]: 149) or not (e.g. Kirkpatrick, Books IV and V, 659).

73 Contra Hossfeld and Zenger, Psalmen 101-150, 189.

74 Hugger arrived at the same understanding of 'my accusers before Yahweh', i.e. at a religious trial ('Ankläger', 107). Booij captures it nicely: 'Such is the work of those agitating before YHWH' ('Psalm 109:6-19 as a Quotation', 100-101). Hugger and Booij are resting their case on the Syr., which is probably more easily explained by a mistaken word division (see the discussion in Allen, Psalms 101-150, 99-100). Nonetheless, it suggests that the sense is not implausible. This, rather than Syr.

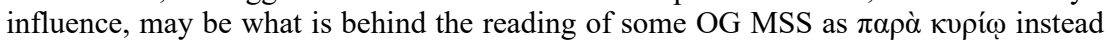
of $\pi \alpha \rho \alpha$ kupíov; the shift from genitive to dative moves the emphasis away from the origin of the accusation and to the location of the accusers (cf. BDAG, 756-57). This seems to have been Zenger's earlier understanding too (A God of Vengeance?, 56).
} 
'because he stands at the right of the needy'), divine defender

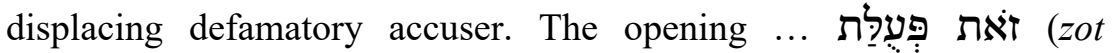
pe'ullat, 'this [has been] the work of') does not merely close the quotation, but identifies the conspirators as responsible. In court, one could only see one man accusing David from his right-hand side. David knows that Yahweh is at his right-hand side, and refers to the cabal of verses 1-5, who in verse 2 have sent the accuser, as they plotted in verses 6-7. They are the ones who are accusing him from Yahweh's presence. A similar expression occurs in verse 27:

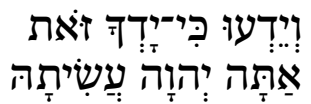

Let them be conscious that this has been your right hand, you, O LORD, have done it!

Yahweh's act of salvation (v. 26) is to be revealed to the enemies as the work of his hand. It would contrast nicely with verse 20 revealing to Yahweh that the one placed at his right hand to accuse is the work of the enemies. The connection may be reinforced by verse 27 picking up a phrase from the verse following verse 20 , which opens with the

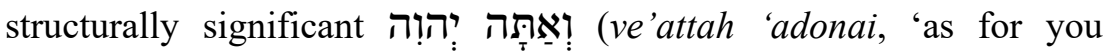
LORD'). Notice their very close phonological correspondence: ${ }^{75}$

verse $21 \mathrm{a}$

verse $27 b$

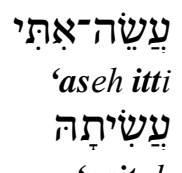

'asitah

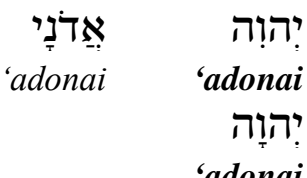

'adonai

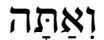 Ve'attah אַתָּרָה 'attah}

Verses 20-21 identify the real miscreants (vv. 2-5) behind the work of accusation (vv. 6-19) in verse $20^{76}$ and turn the matter over to Yahweh for judgement in verse 21. There is no petition in verse 20: what is quoted is not turned on to the accuser's head by David. ${ }^{77}$

\footnotetext{
75 This amply meets the criteria laid down by Adele Berlin, The Dynamics of Biblical Parallelism (rev. \& exp. ed.; Biblical Resource Series; Grand Rapids, Michigan: Eerdmans, 2008): 105.

76 So also Egwim, A Contextual and Cross-Cultural Study of Psalm 109, 149.

77 Contra Day, who argues that v. 20 is jussive, summarising all that has gone before, and functions as a prelude to the climactic 'but you' of v. 21 (Crying, 156 n.5). However, v. 21 is not a climax, but a contrast. It is not clear why a prelude would be needed to summarise a petition right before the climax of that very petition. On my reading, v. 20 adds something distinctive, as does v. 21: v. 20 lays the blame for vv. 619 and v. 21 moves from denunciation to petition. Further, if v. 20 were such a climax,
} 
The similar syntax in verses 28-29 and the strange use of קלל (q-l-l to curse) reinforce this. If verse 20 denounced that זنאת (zot, 'this') was their deed, verse 27 asks that they would know that (zot, 'this') is Yahweh's doing. The following verse picks up the same contrast between them and Yahweh, with a redundant אָתָּ ('attah, 'you'), and a redundant הַָָָּה (hemmah, 'they'). The contrast is between their cursing and Yahweh's blessing. One does not show up in court to curse someone; David is following up his accusation of verse 20, that the charges are not a bona fide legal plea, but a curse from the conspirators. This is ironic, since they are accusing him of cursing. They are to know that their work has been overturned by Yahweh, who blesses instead of cursing.

\section{Structure of Psalm 109}

I offer the following structure (modifying Egwim's). A courtroom accusation is presented as evidence for David's defence in God's court.

1a Superscription

$1 \mathrm{~b}$ Appeal to divine judge and anticipation of verdict

2-20 David's accusation against his enemies

2-5 Accusation against plurality of enemies: they have suborned perjury by sending a wicked accuser to court

6-19 Exhibit A: the private conspiracy of the wicked enemies 6-7 Their private decision to send a slanderous accuser

8-19 Their script for the wicked accuser, which has since been heard in court

8-15 Appeal to the court by false accuser for punishment

16-19 Evidence brought forward by false accuser, arguing that David has earned the sentence of 8-15

20 Claim concerning Exhibit A, restating accusation of 2-5. This has been the plot of the wicked enemies, not the good faith accusation of the man who has been heard in court. They are the מֵאת יִהוֹ (me'et 'adonai)

21-29 Appeal to divine court for acquittal

21 Appeal to justice of court

22-25 Grounds for appeal: protestation of innocence (David is the victim of 16-19)

26 Second appeal to justice of court

'the mild words of v. 29 ... would be quite an anticlimax' (Creager, 'Note on Psalm 109', 122). 
27-29 Desired sentence from court: acquittal of David, shaming of wicked conspirators

30-31 Protestation of innocence

30 Implicit protestation of innocence because of 31

31 All-out wager. Yahweh will take the side of the innocent, whoever that may be. David does not refer to himself in the first person here, but employs the terms of the accusation made against him as a wicked accuser

31a David is innocent. He is not the oppressor of 16, but is himself the oppressed of 22. If he is lying, Yahweh will not take his side

31b He must not merely be acquitted from his wicked accuser in court, but generally be rescued from the wicked conspirators who are accusing him

While Zenger is right (n.39 above) to say that there is a prayer to God to superintend over the court proceedings, Egwim shows convincingly that the prayer is an appeal to Yahweh as the higher court. ${ }^{78}$ Verses 619 are the enemy's words of hate (v. 3) and curse (v. 28). ${ }^{79}$ The evidence for this higher appeal consists of a presentation of the corrupt human courtroom and the unmasking of the unseen conspirators. This means that verses 8-19 (not vv. 6-19) are a quotation (or paraphrase) of what has been said about David in court: the false accuser is hardly going to petition the court to appoint a corrupt official. ${ }^{80}$ Verses 16-19 are the false accuser's evidence against David, which David quotes. ${ }^{81}$ It is not David's evidence, since his case is not against the singular accuser (and vv. 16-19 are singular throughout), but against the wider conspiracy. His equivalent of the יעַן אֶֶׁׁר (ya'an 'asher, 'because') that introduces verses 16-19 is the ( $k i$, 'because') of verse 22, which introduces his own evidence (vv. 22-25) and does so by refuting the claim of verses $16-19$ concerning who is the defenceless victim. David

78 This is close to Seybold's proposal (Psalmen, 434).

79 Seybold identifies vv. 6-20 with v. 3 in this way (Psalmen, 434); Booij identifies vv. 6-19 with v. 3 ('Psalm 109:6-19 as a Quotation', 102).

80 Nonetheless, vv. 6-15 is a unit in the original secret plotting of the wicked enemies, chiastically arranged (Vesco, Le psautier, 1043).

81 Further support for this view comes from Kitz, who identifies the Sitz im Leben of the Psalm as a false accusation that the psalmist took an oath and broke it. On the basis of a parallel text she argues: 'He recounts his enemies' accusations as declarative reports using language drawn from a common oath rite' ('Effective Simile and Effective Act', 455). 
is accused of doing verses 16-19 to someone, while the accusation itself is doing that very thing to him. ${ }^{82}$

\section{Asymmetrical Pleas}

Verses 6-19 are commonly viewed as applying the lex talionis: David was accused of something which would have brought the same punishment upon him. ${ }^{83}$ Even if we accept my reading of verses 6-20, might David seek proportional retribution when he asks for Yahweh to intervene (vv. 21,26)? Does their shaming (v. 28) involve the punishment that they plotted, in line with lex talionis: death and ruin with their families?

We have already argued that verses 6-7 would not be a valid application of such legislation. David asks for much less. His prayer for the wider conspirators is as striking in its mercy as theirs was in its cruelty. ${ }^{84}$ David's use of their own clothing metaphor serves to show the contrast: they pray for curses (v. 19) and he pointedly does not (v. 28).$^{85}$ Instead of asking for them to be clothed in curses, he merely asks for them to be shamed (v. 29).

We cannot assume that shaming implies a death sentence. Bovati argues that shame was an inseparable element of a guilty verdict and therefore very closely linked with the death sentence. Nonetheless, it is experienced before that sentence: they are distinguishable. He cites a number of passages where shame is contrasted with honour or joy: Isaiah 41:11; Psalms 31:17; 37:19-20; 71:13; 83:17; 129:5-6. ${ }^{86}$ However, in each of these passages shaming is the prelude of death, which is mentioned separately. All the more striking that David asks for no such thing here. ${ }^{87}$

82 Thus, while Vesco is right to note that vv. 16-19 describes David's own situation and would therefore be the grounds for David praying vv. 6-15 (Le psautier, 1045), that does not prove that the whole of vv. 6-19 are not a quotation. Such is the irony of David's predicament.

83 So, e.g. Firth, Surrendering, 41.

84 The sharp contrast is often noted (Firth, Surrendering, 41-42; Creager, 'Note on Psalm 109', 122).

85 The contrast in v. 28a is elegantly highlighted with redundant pronouns and economy of words: they curse, but you bless.

86 Ristabilire la Giustizia, 341-42.

87 It is unnecessary to assume that: 'the prayer for Yahweh's vindication of the psalmist to be apparent to all (verses 26-29) assumes that the imprecations sought in verses 6-20 are to be applied' (Firth, Surrendering, 42), since the shame of his enemies 
Willy Stärk commented on Psalm 109 'If we could erase the major central section of this psalm, verses 6-20, we would have one of the most tender prayers of petition that honest piety ever sent up to God out of the suffering of body and soul. ${ }^{88}$ This contrasts with the widespread judgement that $6-20$ is the worst imprecation in the Bible. Even if Stärk overstates the case, David would be praying two irreconcilably different things inside and outside that central passage. ${ }^{89}$

\section{Conclusion}

The aim of this paper has not been to rescue the Psalter from itself. Nothing in the above argument means that the brutal petition in verses 8-15 is necessarily always wrong; it might well be an appropriate response to someone who is guilty of verses 16-19. Its partial use in Acts 1:20 might point in that direction. What we have argued is that David is innocently accused, as explained in verses 1-7 and then verse 20 , and that his prayer for vindication extends from verses 21-31, with 6-19 forming part of his evidence, not part of his request.

would amply demonstrate his own vindication. Frank van der Velden's study of shaming lexemes concludes that they are often associated with wider destruction (Psalm 109 und die Aussagen zur Feindschädigung in den Psalmen [SBB 37; Stuttgart: Katholisches Bibelwerk, 1997]: 92-97). He concludes merely that shaming is not inconsistent with the wider destruction of the enemy asked for in vv. 6-19 (Psalm 109, 96-97). If vv. 16-19 are not petitions from David at all, then we are left with a petition for shaming and nothing more.

88 Cited in Zenger, $A$ God of Vengeance?, 58.

89 As Jangpyo Jung puts it, once vv. 6-19 are identified as an enemy quotation, 'Psalm 109 is no longer to be called a "Psalm of curse"" (A Study of Psalm 109: Its Meaning and Significance in the Context of the Psalter [SBF Thesis AD Doctoratum 424; Jerusalem: Studium Biblicum Franciscanum, 2009]: 130). 